\title{
THE RELATIONSHIP BETWEEN SEEDS CONSUMPTION, LIPID PROFILE AND BODY MASS INDEX AMONG PATIENTS WITH CARDIOVASCULAR DISEASES
}

\author{
Jana Kopčekovál, Petra Lenártovál, Jana Mrázovál, \\ Martina Gažarovál, Marta Habánovál, Kristína Jančichovál
}

${ }^{1}$ Slovak University of Agriculture in Nitra, Faculty of Agrobiology and Food Resources, Department of Human Nutrition, Nitra, Slovak Republic

\begin{abstract}
Background. Cardiovascular disease (CVD) is the leading cause of death worldwide and largely preventable through improving diet quality and other lifestyle factors. In recent years, dietary recommendations have shifted towards diets high in plant-based foods and low in animal-based foods for the prevention of chronic diseases.

Objective. This study aims to evaluate the relationship between seeds consumption, lipid profile and body mass index (BMI) in a group of 889 (313 female and 576 male) randomly selected patients hospitalized in the Nitra Cardio Center, Slovakia.

Material and Methods. The data necessary for the evaluation the relationship between seeds consumption, lipid profiles and BMI were obtained by a questionnaire method in closed-ended format. Data collection was carried out simultaneously with the anthropometric and biochemical examinations of the respondents ensured by the Nitra Cardio Center. The following parameters were assessed in the blood: total cholesterol (T-C), low-density cholesterol (LDL-C), high-density cholesterol (HDL-C), triglycerides (TG), and glucose (GLU). Comparisons between groups were made utilizing one-way analysis of variance (ANOVA) followed by Tukey's post hoc test.

Results. Respondents indicated pumpkin seeds as the most commonly consumed seeds (45.19\% of women and $53.06 \%$ of men) and their preference did not cause changes in lipid profile. Women who consume seeds $1-2$ times/month had significantly lower levels of T-C and LDL-C compared to women non-consuming seeds $(\mathrm{P}<0.05)$. In men, we did not observed any changes in lipid profile. The lowest BMI in women was associated with flaxseed preference and in men with sunflower preference. Increasing frequency of seeds consumption of women and men did not cause changes in BMI. Conclusions. Based on beneficial effects of seeds on cardiovascular risk factors, it seems that seeds consumption can be considered as a useful therapeutic approach for reducing lipid profile and body mass index.
\end{abstract}

Key words: cardiovascular disease, lipid profile, seeds, flaxseed, pumpkin, sunflower, sesame, body mass index

\section{STRESZCZENIE}

Wprowadzenie. Choroby układu krążenia (CVD) są główną przyczyną zgonów na całym świecie i można im w dużej mierze zapobiec poprzez poprawę jakości diety i innych czynników związanych ze stylem życia. W ostatnich latach zalecenia żywieniowe przesunęły się w kierunku diety bogatej w żywność pochodzenia roślinnego i ubogiej w żywność pochodzenia zwierzęcego w celu zapobiegania chorobom przewlekłym.

Cel. Niniejsze badanie ma na celu ocenę związku między spożyciem nasion, profilem lipidowym i BMI w grupie 889 (313 kobiet i 576 mężczyzn) losowo wybranych pacjentów hospitalizowanych w Nitra Cardio Center na Słowacji.

Materiał i metody. Dane niezbędne do oceny zależności między spożyciem nasion, profilami lipidowymi i BMI uzyskano metodą ankietową stosując pytania zamknięte. Zbieranie danych odbywało się równolegle z badaniami antropometrycznymi i biochemicznymi respondentów zapewnianymi przez Centrum Nitra Cardio. Oceniano we krwi stężenia następujących parametrów: cholesterol całkowity (T-C), cholesterol o niskiej gęstości (LDL-C), cholesterol o dużej gęstości (HDL-C), trójglicerydy (TG) i glukozę (GLU) we krwi. Porównania między grupami dokonano wykorzystując jednokierunkową analizę wariancji (ANOVA), a następnie test post hoc Tukeya.

Wyniki. Respondenci wskazali pestki dyni jako najczęściej spożywane nasiona (45,19\% kobiet i 53,06\% mężczyzn), a ich preferencje nie powodowały zmian w profilu lipidowym. Kobiety, które spożywały nasiona 1-2 razy w miesiącu, miały statystycznie znacznie niższy poziom T-C i LDL-C w porównaniu z kobietami nie spożywającymi nasion $(\mathrm{P}<$ 0,05). U mężczyzn nie zaobserwowaliśmy żadnych zmian w profilu lipidowym. Najniższe BMI u kobiet wiązało się

Corresponding author: Jana Kopčeková, Slovak University of Agriculture in Nitra, Faculty of Agrobiology and Food Resources, Department of Human Nutrition, Trieda Andreja Hlinku 2, 94976 Nitra, Slovak Republic, e-mail: Jana.Kopcekova@uniag.sk

(C) Copyright by the National Institute of Public Health - National Institute of Hygiene 
z preferowaniem nasion lnu, a u mężczyzn z preferencją słonecznika. Rosnąca częstotliwość spożycia nasion przez kobiety i mężczyzn nie powodowała zmian wskaźnika BMI.

Wnioski. Opierając się na korzystnym wpływie nasion na czynniki ryzyka chorób układu sercowo-naczyniowego, wydaje się, że spożycie nasion można uznać za przydatne podejście terapeutyczne do obniżania profilu lipidowego i wskaźnika masy ciała.

Słowa kluczowe: choroby układu krążenia, profil lipidowy, nasiona, siemię lniane, dynia, słonecznik, sezam, wskaźnik masy ciata

\section{INTRODUCTION}

Cardiovascular disease (CVD) is the leading cause of death worldwide and largely preventable through improving diet quality and other lifestyle factors [36, 50, 55]. Multiple cardiovascular risk factors, including hyperlipidemia, hypertension, diabetes and smoking are associated with excessive production of reactive oxygen species and increased oxidative stress and inflammation, and promote vascular cell damage. Consequently, increased inflammation and oxidative stress is considered the major mechanism of the pathogenesis of endothelial dysfunction [4, 23]. Diet can affect CVD directly by modulating the composition of vascular plaques, and indirectly by affecting the rate of aging [36].

In recent years, dietary recommendations have shifted towards diets high in plant-based foods and low in animal-based foods for the prevention of chronic diseases [25, 27, 37, 47]. This dietary pattern has been associated with lower risk of CVD [11, 16, 20, 28] and is widely recommended for heart health [32].

Most of these plant-based dietary patterns highlight the intake of nuts as a key component [49, 55]. The integral role of seeds in pre-agricultural diets is understandable given their high energy and nutrient density [52]. In general, they are dense in a variety of nutrients and provide protein, fat (mostly unsaturated fatty acids), dietary fiber and many bioactive constituents such as vitamins (e.g. folic acid, niacin, vitamin $\mathrm{E}$, vitamin $\mathrm{B}_{6}$ ), minerals (e.g. copper, magnesium, potassium, zinc), antioxidants, phytoestrogens and other phytochemicals $[19,50,51$, $54,55]$.

Nuts and edible seeds are recognized for their nutritional value and potential contribution to health promotion $[38,48]$. Nuts and seeds may be considered an important component of a healthy diet and are regularly consumed, either as snacks or part of a meal [19]. In the last decade a large body of scientific evidence has been built on the beneficial effects of increasing consumption of plant seeds and derived products on various health outcomes, chiefly CVD, type 2 diabetes mellitus (T2DM) and intermediate markers [51, 52]. There is substantial evidence that increased consumption of seeds is associated with lower risk of CVD and T2DM or a significant reduction in CVD risk factors such as serum cholesterol or blood pressure [51]. In addition, nuts and edible seeds provide antioxidant, anti-microbial, anti-inflammatory, anti-mutagenic, anti-cancer, antidiabetic and glucoregulatory properties $[30,41]$.

Functional foods with positive effects on health are good choices for reducing the risk of chronic diseases $[8,43]$. Flaxseed is the richest source of plant $\alpha$-linolenic acid (ALA) and lignans [44]. Due to its high content of lignans, fiber, phytosterols and ALA, flaxseed was recently recognized as a functional food that may reduce cardiovascular disease risk factors such as hypertension and hyperlipidemia [8, 13, 14, 17, 29, 46, 62]. Results from studies have reported that some bioactive compounds found in the pumpkin seed oils are mainly polyphenols (phenolic acids, flavonoids, anthocyanins, lignans, and stilbenes), carotenoids (xanthophylls and carotenes) and vitamins (vitamin $\mathrm{E}$ and $\mathrm{C}$ ) act as a natural anti-oxidant $[3,7,12]$. The pumpkin seed oil has also demonstrated various other beneficial properties like anti-microbial, anti-hypertensive, anti-arthritic, anti-inflammatory, and anti-depression activities [2, 33, $61,63]$ and pumpkin seed oil is also well recognized for the treatment of urinary tract infection and other infectious diseases [39]. Sunflower is an excellent source of phenolics and showed the highest antioxidant capacity even though its lignan content is limited. Sesame provide a good source of phenolics, but their peculiar contribution is in term of lignans [21, 60]. This study aims to evaluate the relationship between seeds consumption, lipid profile and body mass index in a group of randomly selected patients hospitalized in the Nitra Cardio Center, Slovakia.

\section{MATERIALS AND METHODS}

\section{Study design and participants}

The study was conducted using the direct PAPI (Paper And Pen Personal Interview) method. A total of 1255 subjects (455 female and 800 male) were recruited, of which 366 were eliminated because they did not answer all of the questions in the questionnaire. Finally, 889 participants (313 females and 576 males) aged 20-101 years were included for further analysis, translating to a response rate of $70.84 \%$. The average age of women was $64.30 \pm 10.03$ years and the average age of men was $60.79 \pm 9.94$ years. Respondents 
included in the study had either overcome myocardial infarction or were diagnosed with angina pectoris and hospitalized after undergoing catheterization. Data were collected during the years 2015-2020.

\section{Ethical aspects}

The research was conducted according to the guidelines of the Declaration of Helsinki and approved by Nitra Cardio Center and by the Ethics Committee at the Specialized Hospital St. Zoerardus Zobor, n. o. Nitra, Slovak Republic (protocol number 10.6.2014).

\section{Dietary data}

The data necessary for the evaluation therelationship between seeds consumption, lipid profiles and BMI were obtained by a questionnaire method in closedended format. The questionnaire was compiled by the Department of Human Nutrition (Slovak University of Agriculture in Nitra) and approved by the Nitra Cardio Center. The questionnaire was applied individually by a single interviewer. The questionnaire contained two parts. The first part included questions concerning the socio-demographic situation of the subjects, physical activity, use of tobacco, and medical history. The second part of the questionnaire concerned the analysis of selected dietary habits, including the number of the consumed meals, their regularity, snacking between meals, types of snacks consumed, and the eating frequency of selected groups of food products. In the dietary questionnaires, we asked participants how often they had consumed a seeds during the preceding year: never, 1-2 times/month or 1-2 times/week. The questionnaire was anonymous; its completion was voluntary, with only one response to be circled for each question.

\section{Biochemical parameters}

Data collection was carried out simultaneously with the somatometric and biochemical examinations of the respondents ensured by the Nitra Cardio Center. All biochemical parameters were measured in certified hospital laboratory using the Automatic Biochemical Analyzer BioMajesty ${ }^{\circledR}$ JCA-BM6010/C (DiaSys Diagnostic System GmbH, Holzheim, Germany). The following parameters were evaluated: total cholesterol (T-C), low-density cholesterol (LDL-C), high-density cholesterol (HDL-C), triglycerides (TG), and glucose (GLU).

\section{Anthropometric parameters}

Anthropometric measurements were performed in the morning with a standard manner (on an empty stomach, after urination and defecation). Anthropometric parameters - body weight $(\mathrm{kg})$ and height $(\mathrm{cm})$ were measured on outpatient electronic medical scales (Tanita WB-3000, Tanita Co., Tokyo, Japan). The body mass index (BMI) was calculated by dividing the body weight in kilograms by the square of the height in meters.

\section{Statistical analysis}

Statistical analysis was carried out using the Statistica version 10 and MS Excel 2007 (Microsoft Corporation, Redmond, Washington, USA). Data were expressed in figures and tables as average \pm standard deviation (SD). We also presented minimum and maximum, categorical variables are reported as percent values. Comparisons between groups were made utilizing one-way analysis of variance (ANOVA) followed by Tukey's post hoc test. The Chi-square test was used for categorical variables. The statistical significance was established at $\mathrm{P}<0.05$.

\section{RESULTS AND DISCUSSION}

\section{Characteristics of study participants}

From the obtained individual values, we calculated the basic statistical characteristics (Table 1).

Of the 889 participants, $481 \quad(54.10 \%)$ were retiree, $559(62.88 \%)$ were married and 331 $(37.23 \%)$ participants had attained a graduation. The demographic characteristics of study participants is shown in Table 2.

Table 1. Basic characteristics of study participants

\begin{tabular}{|c|c|c|c|c|}
\hline \multirow{2}{*}{$\begin{array}{c}\mathrm{n}=889 \\
\text { Parameters }\end{array}$} & \multicolumn{2}{|c|}{ Women $(n=313)$} & \multicolumn{2}{|c|}{ Men $(n=576)$} \\
\hline & average \pm SD & $\min .-\max$ & average \pm SD & $\min .-\max$ \\
\hline Age (yrs) & $64.30 \pm 10.03$ & $35-90$ & $60.79 \pm 9.94$ & $20-101$ \\
\hline BMI $\left(\mathrm{kg} \cdot \mathrm{m}^{-2}\right)$ & $29.31 \pm 4.02$ & $19.00-43.11$ & $29.70 \pm 4.51$ & $17.90-52.01$ \\
\hline T-C (mmol.L $\left.{ }^{-1}\right)$ & $4.83 \pm 1.24$ & $1.95-8.69$ & $4.62 \pm 1.17$ & $1.99-9.18$ \\
\hline LDL-C (mmol.L $\left.{ }^{-1}\right)$ & $2.79 \pm 1.04$ & $0.69-5.89$ & $2.88 \pm 0.98$ & $0.61-7.19$ \\
\hline HDL-C (mmol.L-1) & $1.47 \pm 0.51$ & $0.57-4.55$ & $1.16 \pm 0.39$ & $0.45-4.01$ \\
\hline TG $\left(\mathrm{mmol} . \mathrm{L}^{-1}\right)$ & $1.62 \pm 1.14$ & $0.35-8.27$ & $1.74 \pm 0.93$ & $0.43-7.39$ \\
\hline GLU (mmol.L-1) & $6.92 \pm 3.49$ & $2.23-27.07$ & $6.67 \pm 2.31$ & $3.98-24.12$ \\
\hline
\end{tabular}

Data are expressed as average \pm standard deviation (SD), min. - max.; BMI, body mass index; T-C, total cholesterol; LDL-C, low density cholesterol; HDL-C, high density cholesterol; TG, triglycerides; GLU, glucose 
Table 2. Demographic characteristics of study participants

\begin{tabular}{|c|c|c|c|}
\hline Parameters & $\begin{array}{c}\text { Women }(\mathrm{n}=313) \\
\mathrm{n}(\%)\end{array}$ & $\begin{array}{c}\text { Men }(n=576) \\
n(\%)\end{array}$ & $\begin{array}{c}\text { All participants }(\mathrm{n}=889) \\
\mathrm{n}(\%)\end{array}$ \\
\hline \multicolumn{4}{|l|}{ Social status } \\
\hline employed & 78 (24.92) & 207 (35.94) & $285(32.06)$ \\
\hline unemployed & $25(7.99)$ & $98(17.01)$ & $123(13.84)$ \\
\hline retiree & $210(67.09)$ & $271(47.05)$ & $481(54.10)$ \\
\hline \multicolumn{4}{|l|}{ Family status } \\
\hline married & $158(50.48)$ & $401(69.62)$ & $559(62.88)$ \\
\hline divorced & $52(16.61)$ & $92(15.97)$ & $144(16.20)$ \\
\hline widower & $103(32.91)$ & $83(14.41)$ & $186(20.92)$ \\
\hline \multicolumn{4}{|l|}{ Education } \\
\hline basic & $66(21.09)$ & $67(11.63)$ & $133(14.96)$ \\
\hline apprenticeship & $77(24.60)$ & $176(30.56)$ & $253(28.46)$ \\
\hline graduation & $130(41.53)$ & $201(34.90)$ & $331(37.23)$ \\
\hline higher & $40(12.78)$ & $132(22.92)$ & $172(19.35)$ \\
\hline
\end{tabular}

Basic characteristics of participants based on younger women, lower BMI, fewer smokers, more frequency of seeds consumption

The results revealed significant differences $(\mathrm{P}<$ 0.001) of basic characteristics among three different seeds consumption categories (Table 3 ). Consumption of seeds (1-2 times/week) was most common among physically active, those with positive family history of dyslipidemia, lower alcohol drinking, more consumption of red meat, fruits, vegetables and lower consumption of whole dairy products. We observed different results in men, seed consumption (1-2

Table 3. Basic characteristics of participants based on frequency of seeds consumption

\begin{tabular}{|c|c|c|c|c|}
\hline \multirow{2}{*}{ Characteristics } & \multicolumn{3}{|c|}{ Frequency of consumption seeds } & \multirow{2}{*}{$\mathrm{P}$} \\
\hline & 1-2 times/week & 1-2 times/month & never & \\
\hline \multicolumn{5}{|c|}{ Women $(n=313)$} \\
\hline Age (years) & $63.43 \pm 7.68$ & $64.75 \pm 8.92$ & $63.50 \pm 10.97$ & - \\
\hline BMI (kg.m-2) & $28.31 \pm 3.52$ & $29.49 \pm 4.3$ & $29.74 \pm 4.52$ & - \\
\hline Current Smoking (\%) & 16.00 & 17.54 & 16.13 & $\mathrm{P}<0.001$ \\
\hline Physical activity $<30 \mathrm{~min} /$ day $(\%)$ & 18.67 & 30.70 & 28.23 & $\mathrm{P}<0.001$ \\
\hline Family history of dyslipidemia (\%) & 45.33 & 28.95 & 29.84 & $\mathrm{P}<0.001$ \\
\hline Alcohol >5 drinks/week (\%) & 10.67 & 14.03 & 14.52 & $\mathrm{P}<0.001$ \\
\hline Red meat $>3$ times/week (\%) & 9.33 & 8.77 & 8.87 & $\mathrm{P}<0.05$ \\
\hline Fruits - no daily (\%) & 4.0 & 7.02 & 18.55 & $\mathrm{P}<0.001$ \\
\hline Vegetables - no daily (\%) & 13.33 & 24.56 & 30.65 & $\mathrm{P}<0.001$ \\
\hline Whole dairy product $(\%)$ & 49.33 & 61.40 & 57.26 & $\mathrm{P}<0.001$ \\
\hline \multicolumn{5}{|c|}{ Men $(n=576)$} \\
\hline Age (years) & $61.55 \pm 9.69$ & $59.09 \pm 9.12$ & $61.84 \pm 9.60$ & - \\
\hline BMI $\left(\mathrm{kg} \cdot \mathrm{m}^{-2}\right)$ & $29.57 \pm 3.55$ & $29.60 \pm 4.51$ & $29.67 \pm 5.28$ & - \\
\hline Current Smoking (\%) & 12.62 & 23.96 & 26.17 & $\mathrm{P}<0.001$ \\
\hline Physical activity $<30 \mathrm{~min} /$ day $(\%)$ & 22.33 & 14.75 & 21.88 & $\mathrm{P}<0.001$ \\
\hline Family history of dyslipidemia (\%) & 30.10 & 33.64 & 44.53 & $\mathrm{P}<0.001$ \\
\hline Alcohol >5 drinks/week (\%) & 7.76 & 9.68 & 16.40 & $\mathrm{P}<0.001$ \\
\hline Red meat $>3$ times/week $(\%)$ & 8.74 & 5.99 & 11.71 & $\mathrm{P}<0.001$ \\
\hline Fruits - no daily (\%) & 18.45 & 18.89 & 25.39 & $\mathrm{P}<0.001$ \\
\hline Vegetables - no daily (\%) & 20.39 & 24.42 & 30.86 & $\mathrm{P}<0.001$ \\
\hline Whole dairy product $(\%)$ & 69.97 & 62.67 & 63.28 & $\mathrm{P}<0.001$ \\
\hline
\end{tabular}


times/week) was most common in older men, higher BMI, fewer smokers, less physically active, lower positive family history of dyslipidemia, lower alcohol consumption, higher consumption of fruits, vegetables and whole dairy products.

\section{Effect of the species and frequency of consumption of seeds on lipid profile}

Respondents indicated pumpkin seeds as the most commonly consumed seeds $(45.19 \%$ of women and $53.06 \%$ of men). The second most frequently consumed was sunflower seed which consume $16.74 \%$ of women and $25.55 \%$ of men $(\mathrm{P}<0.001)$ (Figure 1).

Thus, recent studies on pumpkin seed oil indicate that they have gained much attention not only as an edible oil but also as a potential nutraceutical $[3,7$,
$12,35]$. Pumpkin seed is being used traditionally for curing and protecting various ailments [4].

The preference of pumpkin seeds in women and men did not cause changes in lipid profile. The mean serum lipids of participants based on species of seeds consumption is shown in Table 4. Some human clinical trials found that consumption of 30-50 g of flaxseed per day for four to 12 weeks resulted in an $8-14 \%$ decrease in LDL-C levels $[5,15,42,56]$, while other trials did not observe significant reductions in LDL-C after adding 30-40 g flaxseed per day to the diet $[31,34,57]$. Daily consumption of flaxseed (40 g) decreased LDL-C, T-C and TG lipoprotein and increased HDL-C concentrations in healthy menopausal women after 12 months [18]. Significant reductions in T-C, LDL-C and TG levels were seen

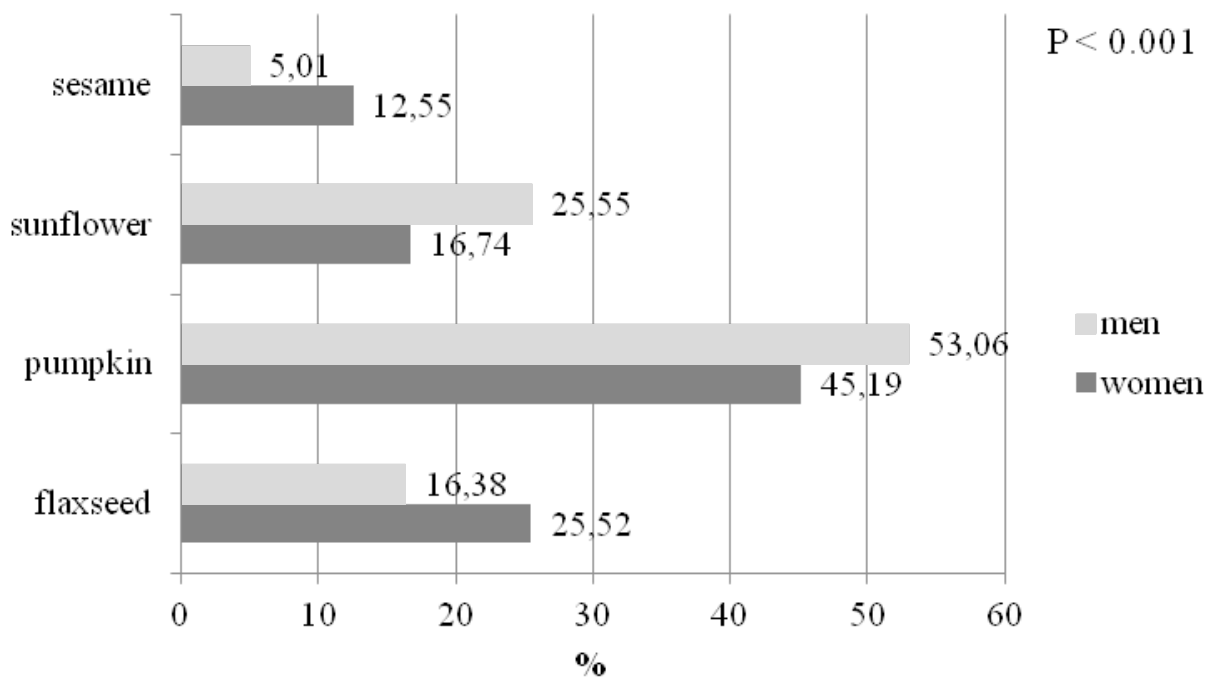

Figure 1. The most frequently consumed seeds $(n=889)$

Table 4. The mean serum lipids of participants based on species of seeds consumption

\begin{tabular}{|c|c|c|c|c|c|}
\hline \multirow{2}{*}{ Species } & \multirow{2}{*}{ n $(\%)$} & \multicolumn{4}{|c|}{ Lipid profile $\left(\mathrm{mmol}^{-\mathrm{L}^{-1}}\right)$} \\
\hline & & $\mathrm{T}-\mathrm{C}$ & HDL-C & LDL-C & TG \\
\hline \multicolumn{6}{|c|}{ Women $(n=313)$} \\
\hline flaxseed & $79(25.52)$ & $4.71 \pm 1.28$ & $1.49 \pm 0.35$ & $2.71 \pm 1.08$ & $1.48 \pm 1.39$ \\
\hline pumpkin & 142 (45.19) & $4.77 \pm 1.11$ & $1.49 \pm 0.59$ & $2.70 \pm 0.94$ & $1.68 \pm 1.04$ \\
\hline sunflower & 53 (16.74) & $4.73 \pm 1.20$ & $1.40 \pm 0.41$ & $2.81 \pm 1.01$ & $1.54 \pm 0.69$ \\
\hline sesame & $39(12.55)$ & $4.19 \pm 1.00$ & $1.37 \pm 0.45$ & $2.53 \pm 0.94$ & $1.58 \pm 0.74$ \\
\hline $\mathrm{P}$ & - & $\mathrm{P}>0.05$ & $\mathrm{P}>0.05$ & $\mathrm{P}>0.05$ & $\mathrm{P}>0.05$ \\
\hline \multicolumn{6}{|c|}{$\operatorname{Men}(n=576)$} \\
\hline flaxseed & $94(16.38)$ & $4.70 \pm 1.21$ & $1.09 \pm 0.24$ & $2.99 \pm 0.94$ & $1.83 \pm 0.96$ \\
\hline pumpkin & $306(53.06)$ & $4.69 \pm 1.28$ & $1.13 \pm 0.45$ & $2.95 \pm 1.02$ & $1.80 \pm 1.00$ \\
\hline sunflower & $147(25.55)$ & $4.60 \pm 1.18$ & $1.15 \pm 0.30$ & $2.91 \pm 1.04$ & $1.57 \pm 0.70$ \\
\hline sesame & $29(5.1)$ & $4.92 \pm 1.34$ & $1.17 \pm 0.45$ & $3.27 \pm 1.16$ & $1.55 \pm 0.80$ \\
\hline $\mathrm{P}$ & - & $\mathrm{P}>0.05$ & $\mathrm{P}>0.05$ & $\mathrm{P}>0.05$ & $\mathrm{P}>0.05$ \\
\hline
\end{tabular}

Data are expressed as average \pm standard deviation (SD); Tukey's post hoc test; T-C, total cholesterol; HDL-C, high density cholesterol; LDL-C, low density cholesterol; TG, triglycerides 
within each group after treatment with flaxseed oil and sunflower oil [1]. Flaxseed supplementation was well-tolerated and resulted in a consistent and significant decrease in T-C and LDL-C levels [29].

We also monitored the mean serum lipids of participants based on frequency of seeds consumption (Table 5). Women who consume seeds 1-2 times/ month had significantly lower levels of T-C and LDL-C compared to women non-consuming seeds $(\mathrm{P}<0.05)$. In men, we did not observed any changes in lipid profile.

Effect of the seeds consumption on body mass index

Nuts and seeds are energy dense foods that have been thought to be positively associated with increased body mass index. Despite the relatively high energy density, intake of nuts was actually associated with less weight gain, lower risk of obesity, and lower risk of moderate weight gain in prospective studies $[6,9,10]$. Some of the reported health benefits derived from nut and seed consumption are control of body weight and blood pressure, reduction of coronary heart disease, and reduction of levels of blood cholesterol and triacylglycerols [30, 45]. Our results show that the different preference and frequency of seeds consumption did not cause changes in BMI. The mean BMI of participants based on species and frequency of seeds consumption is shown in Table 6. Haghighatsiaret et al. [26] demonstrated that incorporating whole flaxseed into the diet of hyperlipidemic and hypertensive patients along with healthy dietary recommendations for 8 weeks could reduce anthropometric measurements - waist circumference (WC) and waist to hip ratio

Table 5. The mean serum lipids of participants based on frequency of seeds consumption

\begin{tabular}{|c|c|c|c|c|c|}
\hline \multirow{2}{*}{ Frequency } & \multicolumn{5}{|c|}{ Parameter (mmol.L-1) } \\
\cline { 2 - 6 } & $\mathrm{n}(\%)$ & T-C & HDL-C & LDL-C & TG \\
\hline \multicolumn{5}{|c|}{ Women (n=313) } \\
\hline $1-2$ times/week & $75(24.03)$ & $4.67 \pm 1.06$ & $1.49 \pm 0.31$ & $2.84 \pm 0.95$ & $1.39 \pm 0.58$ \\
\hline $1-2$ times/month & $114(36.44)$ & $4.77 \pm 1.08^{\mathrm{a}}$ & $1.49 \pm 0.64$ & $2.52 \pm 0.93^{\mathrm{a}}$ & $1.71 \pm 1.10$ \\
\hline never & $124(39.53)$ & $5.05 \pm 1.30^{\mathrm{b}}$ & $1.48 \pm 0.49$ & $2.94 \pm 1.06^{\mathrm{b}}$ & $1.82 \pm 1.51$ \\
\hline $\mathrm{P}$ & - & $\mathrm{P}<0.05$ & $\mathrm{P}>0.05$ & $\mathrm{P}<0.05$ & $\mathrm{P}>0.05$ \\
\hline \multicolumn{5}{|c|}{ Men (n=576) } \\
\hline $1-2$ times/week & $103(17.89)$ & $4.58 \pm 1.17$ & $1.14 \pm 0.50$ & $2.85 \pm 0.94$ & $1.72 \pm 0.95$ \\
\hline $1-2$ times/month & $217(37.60)$ & $4.61 \pm 1.26$ & $1.15 \pm 0.37$ & $2.88 \pm 0.99$ & $1.74 \pm 0.83$ \\
\hline never & $256(44.51)$ & $4.60 \pm 1.03$ & $1.20 \pm 0.37$ & $2.81 \pm 0.90$ & $1.75 \pm 0.84$ \\
\hline $\mathrm{P}$ & - & $\mathrm{P}>0.05$ & $\mathrm{P}>0.05$ & $\mathrm{P}>0.05$ & $\mathrm{P}>0.05$ \\
\hline
\end{tabular}

Data are expressed as average \pm standard deviation (SD); Tukey's post hoc test, different superscript letters in the same column are significantly different; T-C, total cholesterol; HDL-C, high density cholesterol; LDL-C, low density cholesterol; $\mathrm{TG}$, triglycerides

Table 6. The mean BMI of participants based on species and frequency of seeds consumption

\begin{tabular}{|c|c|c|c|c|}
\hline \multirow{2}{*}{ Parameter } & \multicolumn{2}{|c|}{ Women $(\mathrm{n}=313)$} & \multicolumn{2}{c|}{ Men $(\mathrm{n}=576)$} \\
\cline { 2 - 5 } & $\mathrm{n}(\%)$ & BMI $\left(\mathrm{kg} \cdot \mathrm{m}^{-2}\right)$ & $\mathrm{n}(\%)$ & BMI $\left(\mathrm{kg} \cdot \mathrm{m}^{-2}\right)$ \\
\hline Species & $79(25.52)$ & $28.43 \pm 3.42$ & $94(16.38)$ & $30.04 \pm 5.10$ \\
\hline flaxseed & $142(45.19)$ & $29.37 \pm 3.92$ & $306(53.06)$ & $29.74 \pm 4.14$ \\
\hline pumpkin & $53(16.74)$ & $28.89 \pm 3.64$ & $147(25.55)$ & $29.53 \pm 3.58$ \\
\hline sunflower & $39(12.55)$ & $29.95 \pm 4.07$ & $29(5.1)$ & $30.31 \pm 5.89$ \\
\hline sesame & - & $\mathrm{P}>0.05$ & - & $\mathrm{P}>0.05$ \\
\hline $\mathrm{P}$ & $75(24.03)$ & $28.31 \pm 3.52$ & $103(17.89)$ & $29.57 \pm 3.55$ \\
\hline Frequency & $114(36.44)$ & $29.49 \pm 4.3$ & $217(37.60)$ & $29.60 \pm 4.51$ \\
\hline $1-2$ times/week & $124(39.53)$ & $29.74 \pm 4.52$ & $256(44.51)$ & $29.67 \pm 5.28$ \\
\hline $1-2$ times/month & - & $\mathrm{P}>0.05$ & - & $\mathrm{P}>0.05$ \\
\hline never &
\end{tabular}

Data are expressed as average \pm standard deviation (SD);

Tukey's post hoc test; BMI, body mass index 
(WHR) and improve lipid profiles (TG, T-C, and LDL-C) of participants. In the study of O'Neil et al [40] nut consumption was significantly associated with beneficial effects in body mass index, waist circumference, blood pressure, insulin resistance, lower chance of obesity and overweight and increase in HDL-C levels. It is worth mentioning that, in general, an increase in body mass has not been observed with an increased consumption of tree nuts and legume seeds $[22,59]$. However, considerable evidence from both epidemiological studies and clinical trials suggests that nuts are not associated with weight gain and may, in fact, help to lose weight when incorporated to an energy restricted diet [58].

\section{CONCLUSION}

In our study, we observed the associations between consumption of seeds, lipid profile and BMI in a group of randomly selected patients with CVD. Respondents indicated pumpkin seeds as the most commonly consumed seeds and their preference in women and men did not cause changes in lipid profile. Women who consume seeds 1-2 times/month had significantly lower levels of T-C and LDL-C compared to women non-consuming seeds. The lowest BMI in women was associated with flaxseed preference and in men with sunflower preference. Increasing frequency of seeds consumption of women and men did not cause changes of BMI.

Based on beneficial effects of seeds on cardiovascular risk factors, it seems that seeds consumption can be considered as a useful therapeutic approach for reducing lipid profile and body mass index.

\section{Acknowledgments}

This study was supported by the Operational program Integrated Infrastructure within the project: Demand - driven research for the sustainable and innovative food, Drive4SIFood 313011V336, co-financed by the European Regional Development Fund and KEGA 004SPU-4/2019.

\section{Conflict of interest}

The authors declare no conflict of interest.

\section{REFERENCES}

1. Akrami A., Nikaein F., Babajafari S., Faghih S., Yarmohammadi H.: Comparison of the effects of flaxseed oil and sunflower seed oil consumption on serum glucose, lipid profile, blood pressure, and lipid peroxidation in patients with metabolic syndrome. J Clin Lipidol 2018;12(1):70-77. doi: 10.1016/j.jacl.2017.11.004.

2. Allocati N., Masulli M., Alexeyev M.F., Ilio C.D.: Escherichia coli in Europe an overview. Int J Environ Res
Publ Health 2013;10(12):6235-6254. doi: org/ 10.3390/ ijerph10126235.

3. Amin M.Z., Islam T., Mostofa F., Uddin M.J., Rahman M.M., Satter M.A.: Comparative assessment of the physicochemical and biochemical properties of native and hybrid varieties of pumpkin seed and seed oil (Cucurbita maxima Linn.). Heliyon 2019;5(12):e02994. doi: 10.1016/j.heliyon.2019.e02994.

4. Amin M.Z., Rity T.I., Uddin M.R., Rahman M.M., Uddin M.J.: A comparative assessment of anti-inflammatory, anti-oxidant and anti-bacterial activities of hybrid and indigenous varieties of pumpkin (Cucurbita maxima Linn.) seed oil. Biocatal Agric Biotechnol 2020;28:101767. doi: 10.1016/j.bcab.2020.101767.

5. Arjmandi B.H., Khan D.A., Juma S., Drum M.L., Venkatesh S., Sohn E., Wei L., Derman R.: Whole Flaxseed Consumption Lowers Serum LDL-Cholesterol and Lipidprotein Concentrations in Postmenopausal Women. Nutr Res 1998;18(7):1203-1214. doi: 10.1016/ S0271-5317(98)00100-6.

6. Askari G., Yazdekhasti N., Mohammadifard N., Sarrafzadegan N., Bahonar A., Badiei M., Sajjadi F., Taheri M.: The relationship between nut consumption and lipid profile among the Iranian adult population; Isfahan Healthy Heart Program. Eur J Clin Nutr 2013;67(4):385389. doi: 10.1038/ejcn.2013.21.

7. Baiano A., Nobile M.A.D.: Antioxidant compounds from vegetable matrices: Biosynthesis, Occurrence, and extraction systems. Crit Rev Food Sci Nutr 2016;56:2053 2068. doi: 10.1080/10408398.2013.812059.

8. Bloedon M., Szapary P.O.: Flaxseed and cardiovascular risk. Nutr Rev 2004;62(1):18-27. doi: 10.1111/j.17534887.2004.tb00002.x.

9. Bes-Rastrollo M., Sabate J., Gomez-Gracia E., Alonso A., Martinez J.A., Martinez-Gonzalez M.A.: Nut consumption and weight gain in a Mediterranean cohort: the SUN study. Obesity (Silver Spring) 2007;15:107-116. doi: 10.1038/oby.2007.507.

10.Bes-Rastrollo M., Wedick N.M., Martinez-Gonzalez M.A., Li T.Y., Sampson L., Hu F.B.: Prospective study of nut consumption, long-term weight change, and obesity risk in women. Am J Clin Nutr 2009;89:1913-1919. doi: 10.3945/ajcn.2008.27276.

11. Brown M.J., Ferruzzi M.G., Nguyen M.L., Cooper D.A., Eldringe A.L., Schwartz S.J., White W.S.: Carotenoid bioavailability is higher from salads ingested with fullfat than with fat-reduced salad dressings as measured with electrochemical detection. Am J Clin Nutr 2004;80(2):396-403. doi: 10.1093/ajen/80.2.396.

12. Cai Y., Luo Q., Sun M., Corke H.: Antioxidant activity and phenolic compounds of 112 traditional Chinese medicinal plants associated with anticancer. Life Sci 2004;74:2157-2184. doi: 10.1016/j.lfs.2003.09.047.

13. Caligiuri S.P., Edel A.L., Aliani M., Pierce G.N.: Flaxseed for hypertension: Implications for blood pressure regulation. Curr Hypertens Rep 2014;16:499. doi: 10.1007/s11906-014-0499-8.

14. Cassani R.S., Fassini P.G., Silvah J.H., Lima C.M., Marchini J.S.: Impact of weight loss diet associated with flaxseed on inflammatory markers in men with 
cardiovascular risk factors: A clinical study. Nutr J 2015;14:5. doi: 10.1186/1475-2891-14-5.

15. Cunnane S.C., Hamadeh M.J., Liede A.C., Thompson L.U., Wolever T.M., Jenkins D.J.: Nutritional Attributes of Traditional Flaxseed in Healthy Young Adults. Am J Clin Nutr 1995;61(1):62-68. doi: 10.1093/ajen/61.1.62.

16. Diehr P., Beresford S.A.: The relation of dietary patterns to future survival, health, and cardiovascular events in older adults. J Clin Epidemiol 2003;56:1224-1235. doi: 10.1016/s0895-4356(03)00202-6.

17. Dodin S., Cunnane S.C., Mâsse B., Lemay A., Jacques H., Asselin G., Tremblay-Mercier J., Marc I., Lamarche B., Légaré F., Forest JC.: Flaxseed on cardiovascular disease markers in healthy menopausal women: a randomized, double-blind, placebo-controlled trial. Nutrition 2008;24(1):23-30. doi:10.1016/j.nut.2007.09.003.

18. Dodin S., Lemay A., Jacques H., Legare F., Forest J.C., Masse B.: The effects of flaxseed dietary supplement on lipid profile, bone mineral density, and symptoms in menopausal women: a randomized, double-blind, wheat germ placebo-controlled clinical trial. J Clin Endocrinol Metab 2005;90(3):1390-1397. doi:10.1210/jc.2004-1148.

19. Dreher M.L., Maher C.V., Kearney P.: The traditional and emerging role of nuts in healthful diets. Nutr Rev 1996;54:241-245. doi: 10.1111/j.1753-4887.1996.tb03941.x.

20.Fung T.T., Willett W.C., Stampfer M.J., Manson J.E., Hu F.B.: Dietary patterns and the risk of coronary heart disease in women. Arch Intern Med 2001;161:1857-1862. doi: 10.1001/archinte.161.15.1857.

21. Ghisoni S., Chiodelli G., Rocchetti G., Kane D., Lucini L.: UHPLC-ESI-QTOF-MS screening of lignans and other phenolics in dry seeds for human consumption. J Funct Foods 2017;34:229-236. https://doi.org/10.1016/j. jff.2017.04.037.

22. Grosso G., Yang J., Marventano S., Micek A., Galvano F. Kales S.N.: Nut consumption on all-cause, cardiovascular, and cancer mortality risk: a systematic review and meta-analysis of epidemiologic studies. Am J Clin Nutr 2015;101:783-793. doi: 10.3945/ajcn.114.099515.

23. Grover-Paez F., Zavalza-Gomez A.B.: Endothelial dysfunction and cardiovascular risk factors. Diabetes Res Clin Pract 2009;84(1):1-10. doi: 10.1016/j. diabres.2008.12.013.

24.Guasch-Ferre M., Bullo M., Martinez-Gonzalez M.A., Ros E., Corella D, Estruch R., Fitó M., Arós F., Wärnberg J., Fiol M., Lapetra J., Vinyoles E., Lamuela-Raventós RM., Serra-Majem L., Pintó X., Ruiz-Gutiérrez V., Basora J., Salas-Salvadó J.: Frequency of nut consumption and mortality risk in the PREDIMED nutrition intervention trial. BMC Med 2013;11:164. doi: 10.1186/1741-7015-11164.

25. Guasch-Ferre M., Li J., Hu F.B., Salas-Salvado J., Tobias D.K.: Effects of walnut consumption on blood lipids and other cardiovascular risk factors: an updated metaanalysis and systematic review of controlled trials. Am J Clin Nutr 2018;108:174-187. doi: 10.1093/ajen/nqy091.

26.Haghighatsiar N., Askari G., Saraf-Bank S., Feizi A., Keshmiri H.: Effect of flaxseed powder on cardiovascular risk factor in dyslipidemic and hypertensive patients. Int J Prev Med 2019;10:218 doi: 10.4103/ijpvm. IJPVM_563_17.
27. Hartmann M.A.: Plant sterols and the membrane environment. Trends Plant Sci 1998;3:170-175. doi: 10.1016/S1360-1385(98)01233-3.

28.Hu F.B., Rimm E.B., Stampfer M.J., Ascherio A., Spiegelman D., Willett W.C.: Prospective study of major dietary patterns and risk of coronary heart disease in men. Am J Clin Nutr 2000;72:912-921. doi: 10.1093/ ajen/72.4.912.

29. Kanikowska D., Korybalska K., Mickiewicz A., Rutkowski R., Kuchta A., Sato M., Kreft E., Fijatkowski M., Gruchała M., Jankowski M., Bręborowicz A., Witowski J.: Flaxseed (Linum Usitatissimum L.) Supplementation in Patients Undergoing Lipoprotein Apheresis for Severe Hyperlipidemia-A Pilot Study. Nutrients 2020;12(4):1137. doi: 10.3390/nu12041137.

30.Kendall C.W, Josse A.R., Esfahani A., Jenkins D.J.: Nuts, metabolic syndrome and diabetes. $\mathrm{Br} \mathrm{J}$ Nutr 2010;104:465-473. doi: 10.1017/S0007114510001546.

31. Lemay A., Dodin S., Kadri N., Jacques H., Forest, J.C.: Flaxseed Dietary Supplement Versus Hormone Replacement Therapy in Hypercholesterolemic Menopausal Women. Obstet Gynecol 2002;100(3):495504. doi: 10.1016/s0029-7844(02)02123-3.

32.Lichtenstein A.H., Appel L.J., Brands M., Carnethon M., Daniels S., Franch H.A., Franklin B., Kris-Etherton P., Harris W.S., Howard B., Karanja N., Lefevre M., Rudel L., Sacks F., Van Horn L., Winston M., Wylie-Rosett J.: Diet and Lifestyle Recommendations Revision 2006: A Scientific StatementFrom the American Heart Association Nutrition Committee. Circulation 2006;114:82-96. doi: 10.1161/CIRCULATIONAHA.106.176158.

33.Lim J.Y., Yoon J., Hovde C.J.: A brief overview of Escherichia coli 0157:H7 and its plasmid 0157. J Microbiol Biotechnol 2010;20(1):5-14. doi: 10.4014/ jmb.0908.08007.

34.Lucas E. A., Wild R.D., Hammond L.J., Khalil D.A., Juma S., Daggy B.P., Stoecker B.J., Arjmandi B.H.: Flaxseed Improves Lipid Profile Without Altering Biomarkers of Bone Metabolism in Postmenopausal Women. J Clin Endocrinol Metab 2002;87(4):1527-1532. doi:10.1210/ jcem.87.4.8374.

35.Makni M., Fetoui H., Gargouri N.K., Garoui E.M., Jaber H., Makni J., Boudawara T., Zeghal N.: Hypolipidemic and hepatoprotective effects of flax and pumpkin seed mixture rich in $\omega-3$ and $\omega-6$ fatty acids in hypercholesterolemic rats. Food Chem Toxicol 2008;46:3714-3720. doi: 10.1016/j.fct.2008.09.057.

36. Maugeri A., Vinciguerra M.: The Effects of Meal Timing and Frequency, Caloric Restriction, and Fasting on Cardiovascular Health: an Overview. J Lipid Atheroscler 2020;9(1):140-152. doi: 10.12997/jla.2020.9.1.140.

37. Moreau R.A., Nyström L., Whitaker B.D.: Phytosterols and their derivatives: Structural diversity, distribution, metabolism, analysis, and health-promoting uses. Prog Lipid Res 2018;70:35-61. doi: 10.1016/j. plipres.2018.04.001.

38.Naozuka J., Marana S.R., Oliveira P.V: Water-soluble $\mathrm{Cu}, \mathrm{Fe}, \mathrm{Mn}$ and $\mathrm{Zn}$ species in nuts and seeds. J Food Compos Anal 2010;23(1):78-85. https://doi.org/10.1016/j. jfca.2009.08.003. 
39. Nishimura M., Ohkawara T., Sato H., Takeda H., Nishihira J.: Pumpkin Seed Oil Extracted From Cucurbita maxima Improves Urinary Disorder in Human Overactive Bladder. J Tradit Complement Med 2014;4(1):72-74. doi: 10.4103/2225-4110.124355.

40.O'Neil C., Fulgoni V.L., Nicklas T.A.: Tree nut consumption is associated with better adiposity measures and cardiovascular and metabolic syndrome health risk factors in U.S. Adults: NHANES 2005-2010. Nutr J 2015;14:64-72. doi: 10.1186/s12937-015-0052-x.

41. Ostan R., Lanzarini C., Pini E., Scurti M., Vianello D., Bertarelli C., Fabbri C., Izzi M., Palmas G., Biondi F., Martucci M., Bellavista E., Salvioli S., Capri M., Franceschi C., Santoro A.: Inflammaging and cancer: a challenge for the mediterranean diet. Nutrients 2015;7(4):2589-2621. doi: 10.3390/nu7042589.

42.Patade A., Devareddy L., Lucas E.A., Korlagunta K., Daggy B.P., Arjmandi B.H.: Flaxseed Reduces Total and LDL Cholesterol Concentrations in Native American Postmenopausal Women. J Womens Health 2008;17(3):355-366. doi:10.1089/jwh.2007.0359.

43. Poudyal H., Panchal S.K., Diwan V., Brown L.: Omega-3 fatty acids and metabolic syndrome: effects and emerging mechanisms of action. Prog Lipid Res 2011;50:372-387. doi: 10.1016/j.plipres.2011.06.003.

44.Prasad K., Khan A.S., Shoker M.: Flaxseed and Its Components in Treatment of Hyperlipidemia and Cardiovascular Disease. Int J Angiol 2020;29(4):216-222. doi: 10.1055/s-0040-1709129.

45. Rajaei A., Barzegar M., Mobarez A.M., Sahari M.A., Esfahani Z.H.: Antioxidant, anti-microbial and antimutagenicity activities of pistachio (Pistachia vera) green hull extract. Food Chem Toxicol 2010 Jan;48(1):107112. doi: 10.1016/j.fct.2009.09.023.

46.Ras R.T., Geleijnse J.M., Trautwein E.A.: LDLcholesterol-lowering efect of plant sterols and stanols across diferent dose ranges: A meta-analysis of randomised controlled studies. Br J Nutr 2014;112:214219. doi: $10.1017 / \mathrm{S} 0007114514000750$.

47. Rodríguez-García C., Sánchez-Quesada C., Toledo E., Delgado-Rodríguez M., Gaforio J.J.: Naturally Lignan-Rich Foods: A Dietary Tool for Health Promotion? Molecules 2019;24(5):917. doi: 10.3390/ molecules24050917.

48.Rodushkin I., Engström E., Sörlin D., Baxter D.: Levels of inorganic constituents in raw nuts and seeds on the Swedish market. Sci Total Environ 2008;392(2-3):290304. doi: 10.1016/j.scitotenv.2007.11.024.

49. Ros E.: Health benefits of nut consumption. Nutrients 2010; 2:652-682. doi: 10.3390/nu2070652.

50. Ros E.: Nuts and CVD. Br J Nutr 2015;113(2):S111-S120. doi: $10.1017 / \mathrm{S} 0007114514003924$.

51. Ros E., Hu F.B.: Consumption of plant seeds and cardiovascular health: epidemiological and clinical trial evidence. Circulation 2013;128(5):553-565. doi: 10.1161/ CIRCULATIONAHA.112.001119.

52.Ros E., Mataix J.: Fatty acid composition of nutsimplications for cardiovascular health. $\mathrm{Br} \mathrm{J}$ Nutr 2006;96(2)S29-S35. doi: 10.1017/bjn20061861.

53. Salas-Salvado J., Bullo M., Perez-Heras A., Ros E.: Dietary fiber, nuts and cardiovascular diseases. Br J Nutr. 2006;96 Suppl 2:S46-S51. doi: 10.1017/bjn20061863.

54.Salas-Salvado J., Garcia-Arellano A., Estruch R., Marquez-Sandoval F., Corella D., Fiol M., Gómez-Gracia E., Viñoles E., Arós F., Herrera C., Lahoz C., Lapetra J., Perona JS., Muñoz-Aguado D., Martínez-González MA., Ros E.: Components of the Mediterranean-type food pattern and serum inflammatory markers among patients at high risk for cardiovascular disease. Eur J Clin Nutr 2008;62:651-659. doi: 10.1038/sj.ejcn.1602762.

55. Silva A.C.T., Cardozo L.F.M.F., Cruz B.O., Mafra D., Stockler-Pinto M. B.: Nuts and Cardiovascular Diseases: Focus on Brazil Nuts. Int J Cardiovasc Sci 2019; 32(3):274-282. doi: 10.5935/2359-4802.20190016.

56. Simopoulos A.P.: Human requirement for N-3 polyunsaturated fatty acids. Poult Sci 2000;79:961-970. doi: $10.1093 / \mathrm{ps} / 79.7 .961$.

57. Stuglin C., Prasad, K.: Effect of Flaxseed Consumption on Blood Pressure, Serum Lipids, Hemopoetic System and Liver and Kidney Enzymes in Healthy Humans. J Cardiovasc Pharmacol Ther 2005;10(1):23-27. doi: 10.1177/107424840501000103.

58.Tan S.Y., Mattes R.D.: Appetitive, dietary and health effects of almonds consumed with meals or as snacks: a randomized, controlled trial. Eur $\mathrm{J}$ Clin Nutr 2013;67:1205-1214. doi: 10.1038/ejen.2013.184.

59. Tey S.L., Brown R.C., Chisholm A.W., Delahunty C.M., Gray A.R., Williams S.M.: Effects of different forms of hazelnuts on blood lipids and a-tocopherol concentrations in mildly hypercholesterolemic individuals. Eur J Clin Nutr 2011;65:117-124. doi: 10.1038/ejcn.2010.200.

60.Thompson L.U., Cunnane S.C.: Flaxseed in Human Nutrition. New York: AOCS Press; 2003.

61. Todar K.: Pathogenic E. coli. Online Textbook of Bacteriology. University of Wisconsin-Madison Department of Bacteriology. Wisconsin 2007.

62.Vilahur G., Ben-Aicha S., Diaz-Riera E., Badimon L., Padró T.: Phytosterols and Inflammation. Curr Med Chem 2019;26:6724-6734. doi: 10.2174/0929867325666 180622151438 .

63. Yadav M., Jain S., Tomar R., Prasad G.B., Yadav H.: Medicinal and biological potential of pumpkin: an updated review. Nutr Res Rev 2010;23(2):184-190. doi: 10.1017/S0954422410000107.

Received: 29.03 .2021

Accepted: 27.04.2021

Published online first: 04.05.2021 